\title{
Urban water sustainability: framework and application
}

\author{
$\underline{\text { Wu Yang }}^{1}, \underline{\text { David W. Hyndman }}^{2}, \underline{\text { Julie A. Winkler }}^{3}, \underline{\text { Andrés Viña }}^{4}, \underline{\text { Jillian M. Deines }}^{2,4}, \underline{\text { Frank Lupi }}^{4,5}, \underline{\text { Lifeng Luo }}^{3}, \underline{\text { Yunkai Li }}^{6}$,

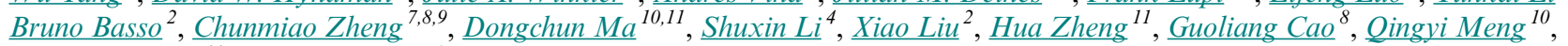 \\ Zhivun Ouvang ${ }^{11}$ and Jianguo Liu $^{4}$
}

\begin{abstract}
Urban areas such as megacities (those with populations greater than 10 million) are hotspots of global water use and thus face intense water management challenges. Urban areas are influenced by local interactions between human and natural systems and interact with distant systems through flows of water, food, energy, people, information, and capital. However, analyses of water sustainability and the management of water flows in urban areas are often fragmented. There is a strong need to apply integrated frameworks to systematically analyze urban water dynamics and factors that influence these dynamics. We apply the framework of telecoupling (socioeconomic and environmental interactions over distances) to analyze urban water issues, using Beijing as a demonstration megacity. Beijing exemplifies the global water sustainability challenge for urban settings. Like many other cities, Beijing has experienced drastic reductions in quantity and quality of both surface water and groundwater over the past several decades; it relies on the import of real and virtual water from sending systems to meet its demand for clean water, and releases polluted water to other systems (spillover systems). The integrative framework we present demonstrates the importance of considering socioeconomic and environmental interactions across telecoupled human and natural systems, which include not only Beijing (the water-receiving system) but also water-sending systems and spillover systems. This framework helps integrate important components of local and distant human-nature interactions and incorporates a wide range of local couplings and telecouplings that affect water dynamics, which in turn generate significant socioeconomic and environmental consequences, including feedback effects. The application of the framework to Beijing reveals many research gaps and management needs. We also provide a foundation to apply the telecoupling framework to better understand and manage water sustainability in other cities around the world.
\end{abstract}

Key Words: environmental governance; megacity; spillover effects; sustainability; systems approach; telecoupling; virtual water; water management

\section{INTRODUCTION}

Rapid population growth, urban expansion, and economic growth pose major water management challenges across the world (Liu and Yang 2012), especially in urban areas (McDonald et al. 2014). The world population rapidly increased from 2.5 billion in 1950 to 7.0 billion in 2011, with a projected growth to 9.3 billion by 2050 (Bloom 2011). In the next four decades, nearly all the growth is expected in urban areas, where the population is projected to increase from 3.9 billion in 2014 to 6.3 billion in 2050 (UN-DESA 2014). Most of the population growth in urban areas will be concentrated in Asia and Africa, with China and India accounting for one-third of the global urban population increase between 2014 and 2050 (UN-DESA 2014).

Megacities (those with populations greater than 10 million) are hotspots of global water use, and thus face enormous water sustainability challenges (United Nations 1998, UN-HABITAT 2008, WWF 2011). Globally, the number of megacities increased from just two (Tokyo and New York) in 1950 to 28 in 2014, with 41 expected by 2030 (UN-DESA 2014). Meanwhile, the number of inhabitants in megacities increased from 23.6 million in 1950 to 453 million in 2014 , and is expected to reach 730 million by 2030 (UN-DESA 2014). The rapid growth of megacities in recent decades has resulted in a significant lag in management capacities compared to earlier periods of lower urban growth when megacities were able to progressively build infrastructure and innovative governance (Varis et al. 2006).

Urban areas are increasingly interacting with other regions through flows of water, food, energy, people, information, and capital. Based on our compiled statistics, 22 of the 28 megacities $(79 \%)$ currently rely on distant water transfers to meet their needs (United Nations 2014). A large proportion of the food for cities is also imported, and importing food is equivalent to importing virtual water (i.e., the consumed water for producing a traded product but is not shown in the form of real water). As a result, megacities affect water dynamics well beyond their boundaries.

To date, analyses and management of water sustainability in urban areas, such as megacities, have been largely fragmented and often focus only on a subset of the major components. For instance, some have focused on internal interactions (Bidhendi et al. 2008, Lorenzen et al. 2010, Bai et al. 2012), distant interactions (Sohel et al. 2003, Abraham 2010, Deines et al. 2016), socioeconomic interactions ( $\mathrm{Li}$ and Shi 2003, Bidhendi et al. 2008), or environmental interactions (Tortajada and Castelan 2003, Lorenzen et al. 2010, Bai et al. 2012, Yan et al. 2012). This is partially due to insufficient integrated conceptual frameworks that systematically analyze various components simultaneously.

${ }^{1}$ Department of Environmental Science, Zhejiang University, China, ${ }^{2}$ Department of Earth and Environmental Sciences, Michigan State University, USA, ${ }^{3}$ Department of Geography, Michigan State University, USA, ${ }^{4}$ Center for Systems Integration and Sustainability, Department of Fisheries and Wildlife, Michigan State University, USA, ${ }^{5}$ Department of Agricultural, Food, and Resource Economics, Michigan State University, USA, ${ }^{6}$ Department of Hydraulic Engineering, China Agriculture University, China, ${ }^{7}$ School of Environmental Science and Engineering, South University of Science and Technology of China, China, ${ }^{8}$ Center for Water Research, College of Engineering, Peking University, China, ${ }^{9}$ Department of Geological Sciences, University of Alabama, USA, ${ }^{10}$ Beijing Water Science and Technology Institute, China, ${ }^{11}$ State Key Lab of Urban and Regional Ecology, Research Center for Eco-environmental Sciences, Chinese Academy of Sciences, China 
Fig. 1. Conceptual framework for analyzing urban water sustainability. Arrows indicate directions of interactions and feedbacks. For the sake of simplification, the figure does not show causes, agents, and effects in sending, receiving, and spillover systems; local couplings within sending and spillover systems; or other flows (except water) of people, technology, and knowledge between systems. For more descriptions, please refer to the text.

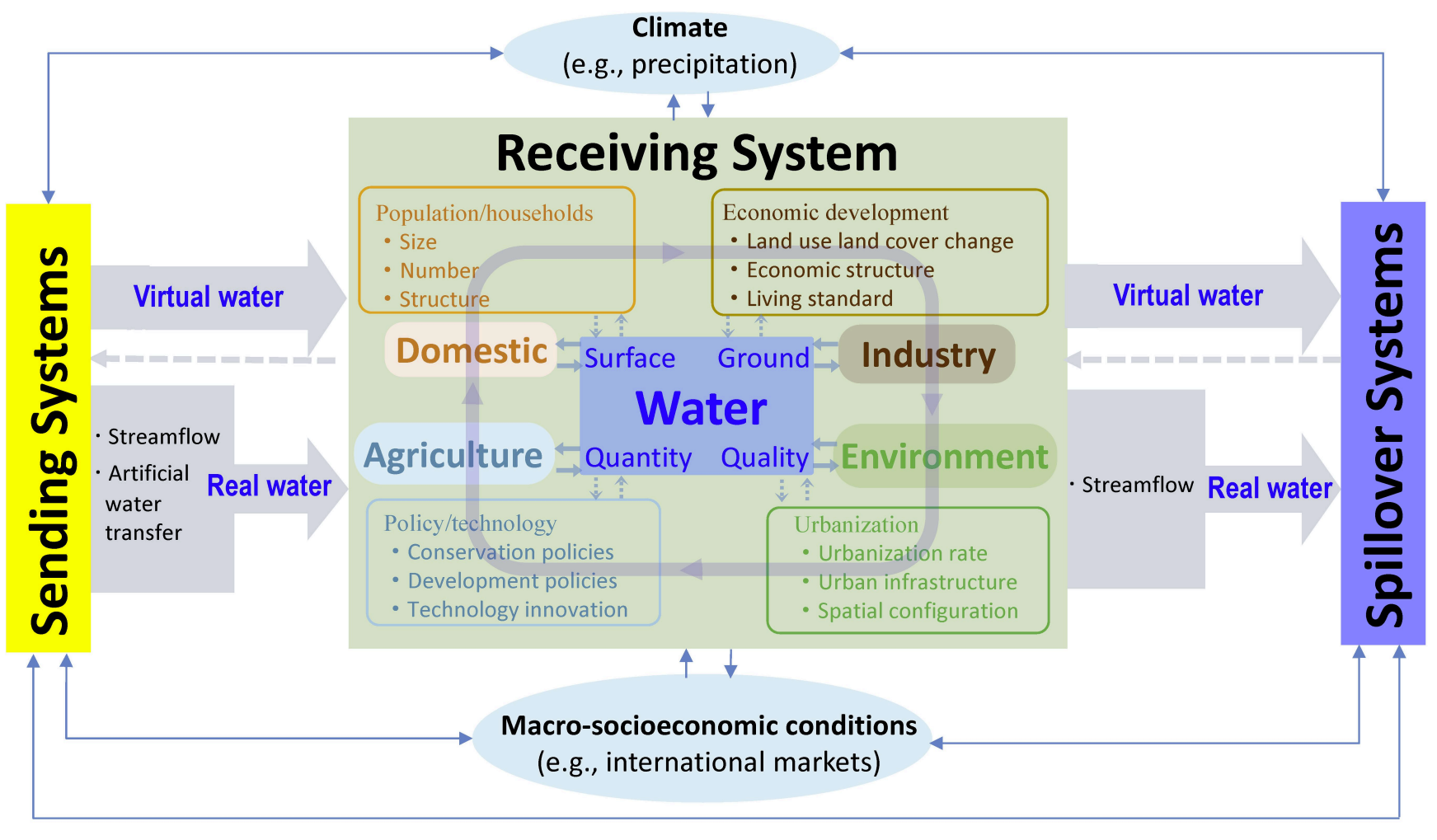

We apply the integrated framework of telecoupling (socioeconomic and environmental interactions over distances) to analyze and understand urban water dynamics, using the megacity of Beijing as a demonstration. We begin with an overview of the framework and a description of the demonstration megacity. Then we describe water dynamics in Beijing and factors influencing such dynamics. After highlighting major local couplings and telecouplings that affect Beijing's water dynamics, we illustrate some environmental and socioeconomic consequences of these water dynamics. Finally, we discuss research gaps and implications for water policy and management.

\section{OVERVIEW OF A TELECOUPLING FRAMEWORK FOR URBAN WATER SUSTAINABILITY}

Urban areas depend on many distant areas, both socioeconomically and environmentally, through real water or virtual water transfers. Thus, to systematically address urban water sustainability, it is essential to place all major relevant issues under a conceptual framework that integrates socioeconomic and environmental interactions within and outside urban areas.

Among existing conceptual frameworks (e.g., Ostrom 2009, Binder et al. 2013), the telecoupling framework proposed by Liu et al. (2013) has considerable potential for analyzing urban water issues because it uses a systems approach and places water sustainability in the context of coupled human and natural systems. The framework views each place (e.g., a city) as a coupled human and natural system in which humans and natural components interact (Liu et al. 2007). It considers important relevant factors and their interactions within and between coupled systems. Interactions within a coupled system are internal local couplings, while those between distant coupled systems are referred to as telecouplings. The telecoupling framework includes five major interrelated components: agents, flows, systems, causes, and effects. A telecoupling is generated by agents that facilitate the flows (exchanges of energy, information, and material such as water) among the coupled human and natural systems. Based on the directions of flows, systems can be categorized as sending systems (origins), receiving systems (destinations), and spillover systems (those that influence, and are influenced by, interactions between sending and receiving systems) (Fig. 1). Causes are drivers or factors that generate a telecoupling between two or more systems, which produce socioeconomic and environmental effects in one or more of the systems. The framework also considers feedbacks (i.e., reciprocal interactions among coupled systems). It should be pointed out that "over distances" in the telecoupling framework is relative, similar to other relative concepts that do not have fixed values, such as "ecosystems," which can be as small as a pond or as large as the entire planet depending on the questions and research objectives. Such flexibility has helped advance ecology enormously. The flexibility 
of the telecoupling concept may play a similar powerful role because it can accommodate various situations. Furthermore, not all systems need to be far away.

The concept of telecoupling naturally extends the concept of "coupling" within a system to interactions across two or more distant coupled systems. Furthermore, similar to the umbrella concept of "ecosystem services," which includes diverse types of benefits from ecosystems to humans, the concept of telecoupling encompasses multiple types of distant interactions and can facilitate the understanding of relationships among these interactions (Liu et al. 2015a). It is more comprehensive than concepts of relevant distant interactions in traditional disciplinary research. For instance, it expands the concept of teleconnection in atmospheric science that refers to the relationships between climate anomalies at distant locations (typically thousands of kilometers) by adding socioeconomic interactions, and extends the concept of economic globalization (interactions between distant human systems) by encompassing environmental interactions (Liu et al. 2013).

The telecoupling framework differs in several aspects from other coupled systems frameworks, such as those analyzed by Binder et al. (2013) and Liu et al. (2016). First, other frameworks concentrate largely on interactions within a coupled system. The telecoupling framework integrates both socioeconomic and environmental interactions between the focal coupled systems and other coupled systems, along with those within a particular system. Second, although some frameworks pay attention to the effects of external factors on the focal system, they do not consider the effects of the focal system on other systems. Because urban areas rely on resources from other systems and influence other systems (e.g., provide goods, products, technology, and pollutants) (Liu et al. 2015b), explicit considerations of the interactions with other systems are particularly important. Third, some frameworks consider interactions between sending and receiving systems, but they pay little or no attention to spillover systems. The telecoupling framework offers an explicit approach to incorporate spillover systems to internalize socioeconomic and environmental externalities across space, as spatial externalities are widespread and significant (Brock and Xepapadeas 2010, Bithas 2011). The effects in the telecoupling framework may or may not be quantifiable or measurable. For quantifiable effects, the telecoupling framework can be used to provide quantitative results on the telecoupling processes. For nonquantifiable effects, the telecoupling framework may also improve qualitative understanding of the relationships between agents, flows, causes, and effects from a holistic perspective.

In addition, the telecoupling framework can integrate and extend existing approaches for quantifying distant effects and flows of urban water use. For example, the ecological footprint concept (Wackernagel and Rees 1996) has been used to quantify the land area required to supply the water needs of large cities (e.g., Jenerette and Larsen 2006) but fails to identify these sending systems. By incorporating agents, causes, flows, and effects of specific sending systems, the telecoupling framework provides an increased depth of understanding of the urban water footprint that is crucial to effective and sustainable management. Moreover, ecological footprint can be one of the measures for "effects" in the telecoupling framework or an early screening tool to identify urban areas with a large externalized water footprint that would benefit from a more rigorous telecoupling analysis. Similarly, urban metabolism approaches (Wolman 1965) applied to water seek to quantify all water fluxes into, within, and out of a city, with particular focus on assessing sustainability in both water quantity and quality. Previous work under this framework can offer methodologies for flow quantification (e.g., ecological network analysis [Zhang et al. 2010]) that are useful to telecoupling studies, while the telecoupling framework extends beyond snapshots of current water flows by incorporating the agents and causes responsible, and notably, the coupled systems outside the urban extent.

To date, the telecoupling framework has been successfully applied to a number of important issues, including ecosystem services (Liu and Yang 2013, Liu et al. 2016); conservation (Gasparri et al. 2015); trade of food (Liu et al. 2013, 2015b); forest products (Liu 2014); fertilizers and plastic films for agriculture (Liu et al. 2015a); energy and virtual water (Liu et al. 2015b); information dissemination, tourism, and panda loans (Liu et al. 2015a); land change science (Eakin et al. 2014, Liu et al. 2014, Wicke 2014); international land sales (Liu et al. 2014); and species invasion (Liu et al. 2013, 2014). We illustrate the megacity water concerns using the telecoupling framework.

Because many cities receive more water than they send out, we view them as receiving systems of water. Accordingly, we regard areas with net water export to cities as sending systems, and areas affected by interactions between sending and receiving systems as spillover systems (Fig. 1). Within a coupled system, quantity and quality of both surface water and groundwater are affected by multiple interactive human and natural factors (Fig. 1). Water users can be divided into four main categories: domestic, industry, agriculture, and environment (Fig. 1). Domestic users (e.g., households) need water for drinking, cooking, and washing. Population size and household number as well as demographic structure (e.g., age, gender) affect domestic water use. As household number and population size increase, water use also increases, often in a nonlinear manner. Economic development, including industry, also requires water, and changes in land use and land cover in turn alter water availability and use. Agricultural areas surround urban areas, and some crops require irrigation water. The environment also needs water for ecosystem processes and functions.

Policy and technology (e.g., wastewater recycling, stormwater collection, water pricing, and irrigation technology) can expand the water supply and mediate water use by changing the demand and efficiency of use. Precipitation (one of the main climate factors) increases water quantity, while overland flow removes water from the region where the precipitation falls and reduces water quantity (Fig. 1).

Water dynamics within a coupled system are also affected by telecoupling processes such as imports and exports of real and virtual water (Fig. 1). Water demand and supply are the major causes behind such telecoupling processes. Water importation may be achieved via water flows through streamflow, water transfer projects, bottled water, and movement of virtual water (Fig. 1). Even when there is a need to import water, some water exports may still exist through streamflows and virtual water trade (Fig. 1). Water imports and exports may be facilitated by agents, 
Fig. 2. Map of Beijing with urban areas highlighted in 1972 and 2007, along with reservoirs, rivers, and lakes. Data from Li et al. (2013).

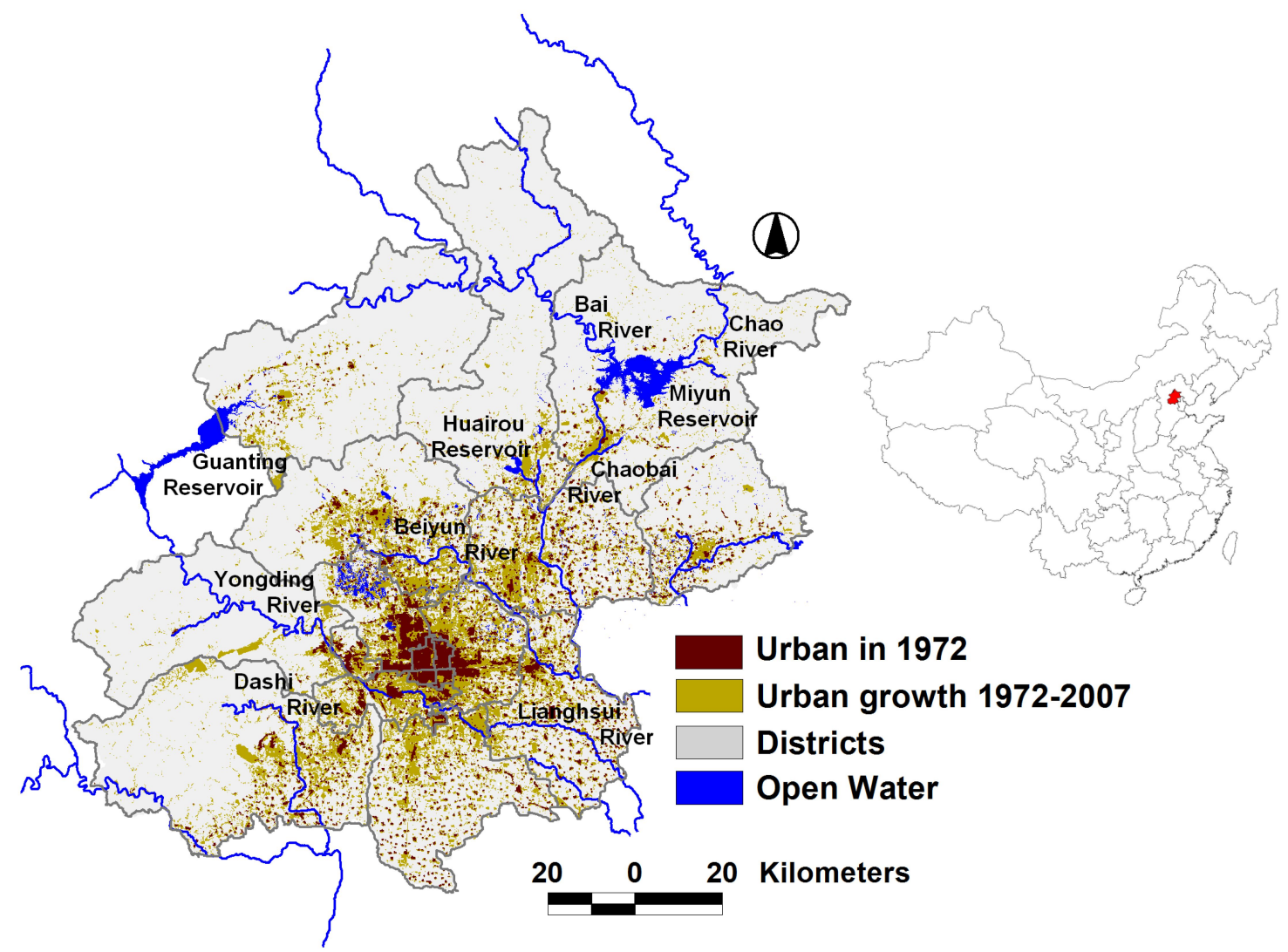

such as water users that create demand for water, policy-makers who develop and sign transfer agreements, and companies that conduct distant commodity purchases and sales. Together with local couplings, telecouplings affect water dynamics, which in turn have socioeconomic and environmental effects (Fig. 1). For example, water shortages may increase competition for water, increase water price, limit people's access to water, lead to political disputes and social unrest, and damage the environment. Also, there are feedbacks among receiving, sending, and spillover systems (Fig. 1). All these systems affect and are affected by climate and macro-socioeconomic conditions (Fig. 1).

\section{OVERVIEW OF THE MEGACITY OF BEIJING}

In China, "city" is an administrative unit. It normally includes a metropolis (core urban districts) and some rural areas with rural populations in counties or districts. Hence, here, Beijing (or Beijing City) refers to the entire land area within the municipal boundary rather than just the core urban area. Beijing exemplifies the global challenge of achieving urban water sustainability because of its rapid population growth, urbanization, and economic development. It is situated on the northwest edge of the North China Plain, with nearly two-thirds of the city in the Taihang and Yan mountains to the northwest and the remainder in the Beijing Plain. The city covers $\sim 16,410 \mathrm{~km}^{2}$ and includes 16 districts (two core urban districts totaling $92 \mathrm{~km}^{2}$, four inner suburbs totaling $1276 \mathrm{~km}^{2}$, and 10 outer suburbs totaling 15,042 $\mathrm{km}^{2}$ ) (Fig. 2).

Beijing experienced rapid demographic and economic changes in the past three decades. Its total permanent population (i.e., residential population) was 9.2 million in 1982, exceeded 10 million in 1986, and reached 21.7 million by 2015 (Beijing Bureau of Statistics 1980-2015). According to China's 2010 population census, Beijing's average household size for the permanent population declined from 3.7 members per household in 1982 to 2.5 in 2010. Per capita gross domestic product soared from US\$821 in 1986 to US\$17,064 in 2015 (Beijing Bureau of Statistics 1980-2015).

\section{WATER DYNAMICS IN BEIJING}

The average annual volume of locally available water for Beijing between the $1950 \mathrm{~s}$ and $2010 \mathrm{~s}$ was approximately 4 billion $\mathrm{m}^{3}$ (varying from 1.6 to $9.7 \mathrm{~m}^{3}$ ) (Fig. 3a). Per capita water resources declined from $\sim 1000 \mathrm{~m}^{3}$ in 1949 to $\sim 100 \mathrm{~m}^{3}$ in 2011 , which is only $1 / 24^{\text {th }}$ of the national average or $1 / 90^{\text {th }}$ of the world average (Beijing Water Authority 1986-2012, Hao 2012), and is far below the international severe water scarcity standard of $1000 \mathrm{~m}^{3}$ per capita (Falkenmark and Widstrand 1992, Gleick 1995). In 2014, the total volume of renewable water resources for Beijing was 2.03 billion $\mathrm{m}^{3}$, with 0.65 and 1.38 billion $\mathrm{m}^{3}$ from surface water and groundwater, respectively. The per capita availability was only 94.9 $\mathrm{m}^{3}$, making it one of the world's most water scarce cities. 
Fig. 3. Estimates of (a) surface water and groundwater resources, along with the total of these two, in Beijing, and (b) precipitation, inflows, and outflows of reservoirs. Inflows and outflows refer to streamflows. Data from Water Resource Administration Division of Beijing Water Resource Bureau and Beijing Water Resource Bulletin 1986-2015.

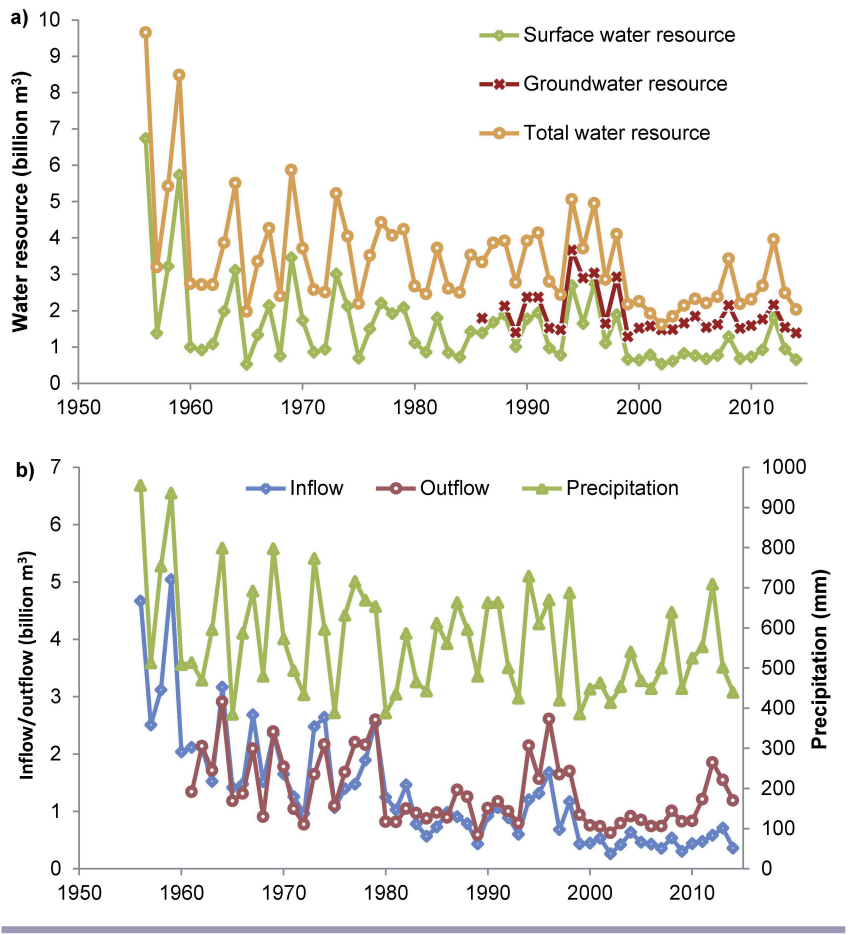

\section{Surface water dynamics}

Situated in the Haihe River basin, Beijing has access to 108 streams with catchment areas larger than $50 \mathrm{~km}^{2}$; these constitute five main natural drainages: the Yongding, Beiyun, Chaobai, Daqing, and Jiyun rivers (Meng et al. 2012). The average annual streamflow of these five main rivers is approximately 1.8 billion $\mathrm{m}^{3}$, of which the Chaobai and Beiyun rivers accounted for $64 \%$ of the multiyear average from 1956 to 2010 (Beijing Water Authority 1986-2012). Primarily due to human activities, natural inflows have declined over time. The water flows of the Yongding River became intermittent dating back to the 1960s. The average annual days without water reached 282 and 299 in the 1970s and 1980 s, respectively, and after the 1990s, there was no water flow in the downstream portions of the Yongding River. Similarly, based on monitoring observations from the Suzhuang hydrological station, the average annual runoff of the Chaobai River declined by $52 \%$ (from 2.64 to 1.25 billion $\mathrm{m}^{3}$ ) from the 1950 s to the $2000 \mathrm{~s}$. The severe decline in flow of these two major rivers forced Beijing to exploit groundwater to meet its soaring water demand (Jiao 2008).

Precipitation is the main renewable source of water for Beijing, and its variability is one of the major factors affecting surface water and groundwater storage. Overall, the Beijing Plain has more precipitation (796 $\mathrm{mm}$ in 2012) than the surrounding mountainous area (656 $\mathrm{mm}$ in 2012) (Beijing Water Authority
2012). Beijing's precipitation had strong seasonal variations, with most precipitation falling from late July to mid-August, and has experienced a decreasing trend over the past six decades (Fig. 3b).

In response to spatial and temporal variability in precipitation, between 1949 and 2011, Beijing converted most of the natural river system into canals (Mansell and Wang 2010) and constructed 88 reservoirs with a total capacity of 93.8 billion $\mathrm{m}^{3}$, most of which held little water during a recent prolonged drought (Beijing Water Authority \& Beijing Bureau of Statistics 2013). The two largest reservoirs are Guanting and Miyun (Fig. 2), with total capacities of 4.2 and 4.4 billion $\mathrm{m}^{3}$, respectively, although they held only 0.33 and 1.03 billion $\mathrm{m}^{3}$ of water in 2015 (Fig. 4). The entire Miyun Reservoir is inside the administrative boundary of Beijing, while most of the Guanting Reservoir is located in Hebei Province and thus can be considered a water-sending system for Beijing. Neither of these reservoirs have supplied water for agricultural use since the mid-1980s, which has further aggravated the exploitation of groundwater.

Fig. 4. Estimates of annual water inflow, outflow, and storage in (a) Guanting Reservoir and (b) Miyun Reservoir. Data from Water Resource Administration Division of Beijing Water Resource Bureau and Jiao (2008).
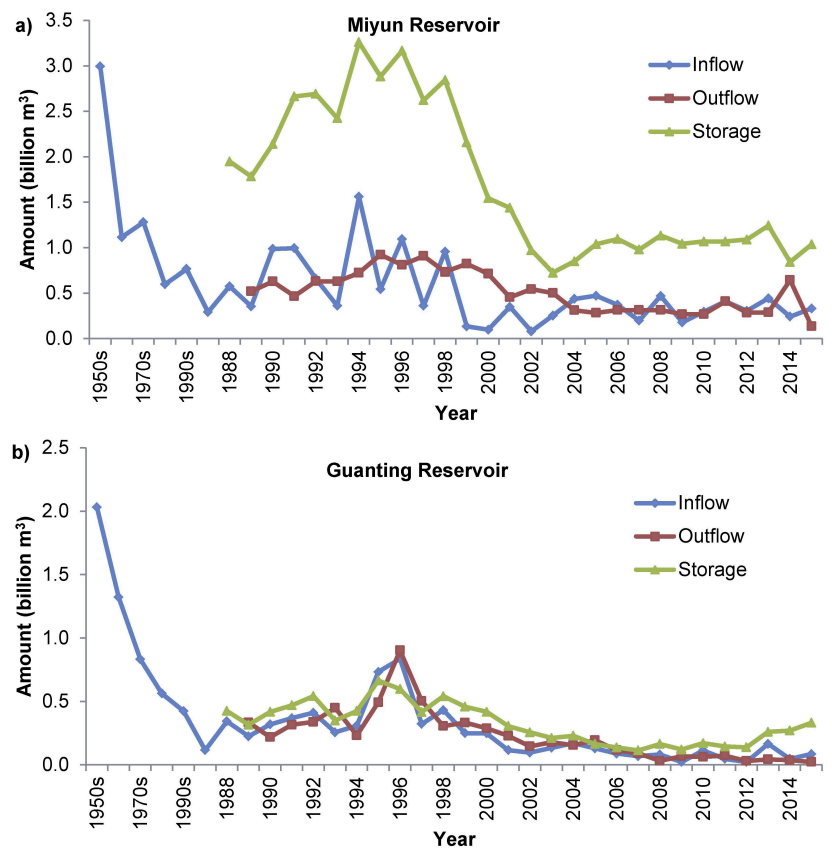

\section{Groundwater dynamics}

Since the Ming (1368-1644) and Qing (1644-1912) dynasties, with the introduction of drilling technology, groundwater has been increasingly exploited. In 1949, there were 123 wells, annually extracting 8.03 million $\mathrm{m}^{3}$ of groundwater (Zhou et al. 2013). By 2011 , the number of wells had increased to 84,748 , of which 62,645 had powered pumps, 17,887 had manual pumps, and 4216 were abandoned. Of those with manual pumps, $62 \%, 31 \%$, and $7 \%$ were for agricultural, domestic, and industrial uses, respectively (Beijing Water Authority \& Beijing Bureau of Statistics 2013). As of 2011, almost two-thirds of the water supply in Beijing came from groundwater. 
Since 1981, Beijing has managed its groundwater through licensing permits, charging water resources fees, and setting increasing block tariffs that go to conservation funds for water. Such measures, combined with a series of water-saving and science-based management approaches, provided some protection for groundwater resources. In suburban districts, the average annual exploitation declined from 0.9 billion $\mathrm{m}^{3}$ in the 1970 s to 0.75 billion $\mathrm{m}^{3}$ in the 1990s (Zhang et al. 2008). From 2001 to 2014, the total groundwater use continued to decrease from 2.7 to 1.8 billion $\mathrm{m}^{3}$, of which agriculture use declined from 1.7 to 0.8 billion $\mathrm{m}^{3}$ over this same period (Fig. 5). Despite such recent progress in the reduction of groundwater use, the total annual water use of 3.5 to 4 billion $\mathrm{m}^{3}$ (Fig. 5) continues to be considerably higher than the total naturally renewable water resources represented as inflows in Fig. 3.

Fig. 5. (a) Annual water use by sources and sectors (diverted and recycled water included) from 1980 to 2014. (b) Detailed annual sources of water supply used in Beijing from 2001 to 2014. The official statistics of environmental water use started in 2000. Data before 2000 are from Yan (1999:15). Other data are from Beijing Statistic Yearbook (2015). SNWTP: South-toNorth Water Transfer Project

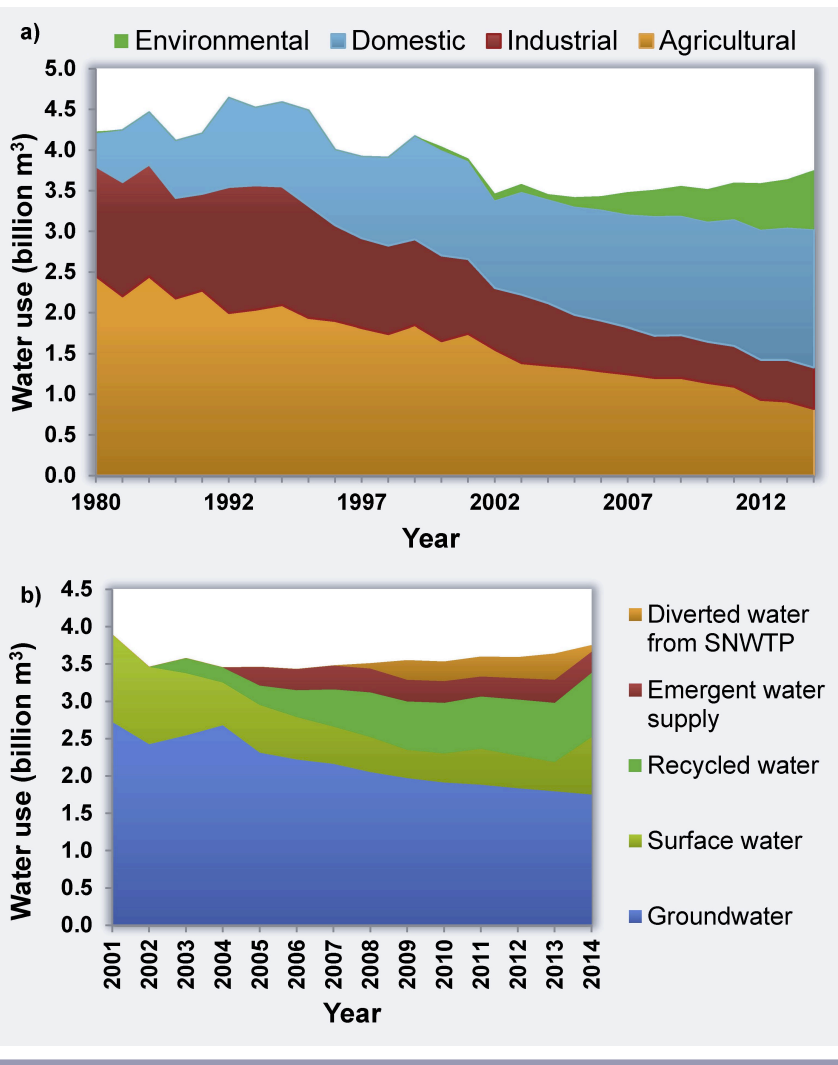

In the 1960s, the water table below the Beijing Plain was in a relatively natural state with little human disturbance, and with natural flows from the higher water level areas near the mountains to the northwest toward the southeast (Fig. 6). Beginning in the 1970s, with rapid industrial development and increased groundwater extraction in inner suburban areas, the water table started to decline, forming a massive cone of depression near the center of the municipality (Fig. 6), while in the outer suburbs, the water table was closer to its natural state. In the 1980 s, the extended droughts and the drying of the Chaobai River decreased groundwater recharge and increased exploitation, causing several cones of depression to form in the eastern and northeastern parts of the inner suburban areas (Fig. 6). In the 1990s, although there was control of groundwater extraction, groundwater levels continued to decline in the central urban region (Fig. 6) where exploitation was intensive. A 9-year drought from 1999 to 2008, along with an average annual exploitation of 0.57 billion $\mathrm{m}^{3}$, resulted in a drop in the average groundwater level from $11.9 \mathrm{~m}$ to $22.9 \mathrm{~m}$ below ground surface between 1998 and 2011 (Zhang et al. 2008, Beijing Water Resource Bulletin 2011).

\section{FACTORS AFFECTING WATER DYNAMICS IN BEIJING}

Here, we provide specific illustrations of how both local couplings and telecouplings affect water dynamics in Beijing.

\section{Local couplings}

Local couplings include local water use and measures to reduce water use (feedbacks). From the 1950s to the 2000s, there was a $39 \%$ reduction in areal average precipitation in Beijing (Fig. 3). Total annual water use peaked in the early 1990s, then gradually decreased to a relatively stable rate of approximately 3.5 billion $\mathrm{m}^{3} \cdot \mathrm{yr}^{-1}$ after 2001 (Fig. 5a). The relative importance of the four major types of water users varied over time. Annual agricultural and industrial water uses decreased by $66.7 \%$ ( 2.4 to 0.8 billion $\mathrm{m}^{3}$ ) and $62.9 \%$ (1.4 to 0.5 billion $\left.\mathrm{m}^{3}\right)$ from 1980 to 2014 , respectively. Over this same period, domestic and environmental water uses increased by 3.3 times $\left(0.4\right.$ to 1.7 billion $\left.\mathrm{m}^{3}\right)$ and 39.3 times $\left(0.018\right.$ to 0.725 billion $\left.\mathrm{m}^{3}\right)$, respectively. In terms of percentages, from 1980 to 2014, agricultural and industrial uses declined from $58.1 \%$ to $21.8 \%$, and $32.1 \%$ to $13.6 \%$, respectively; meanwhile, domestic and environmental uses increased from $9.8 \%$ to $45.3 \%$, and $0.4 \%$ to $19.3 \%$, respectively.

The soaring amount of domestic water use was driven primarily by rapid population growth and household proliferation (Liu et al. 2003). From 1978 to 2011, Beijing's immigrant population, residential population, and residential households increased by 36.8 times, 0.5 times, and 1.4 times, respectively (Beijing Bureau of Statistics 1980-2012). Relative to $337 \mathrm{~km}^{2}$ of urban built-up area in 1984, the total built-up area in Beijing increased by $136 \%$ in 2000 and $256 \%$ in 2010 ( $\mathrm{Li}$ et al. 2013). Furthermore, the environmental and socioeconomic interactions between the two rural districts (Miyun and Huairou) and the urban zone (Fig. 2) are among the most proximate local couplings within Beijing. Such rural-urban interactions affect water dynamics. For example, the Miyun Reservoir provides drinking water for the urban zone. Furthermore, rural farmers cultivate agricultural products with embedded virtual water and sell their products to people within the urban zone. Urban residents often spend weekends in rural districts to enjoy clean air, scenic views, and outdoor activities, and consequently, consume domestic water in rural districts. This local tourism provides additional revenue for rural households, which allows them to purchase industrial products (e.g., clothes, household appliances) that embed virtual water.

To address water supply challenges, Beijing has taken a series of actions (feedbacks) to reduce water use. Beijing is among the most active cities promoting water-saving policies, wastewater 
Fig. 6. Maps of groundwater level for the plain area of Beijing (mountainous area in the west is not shown) in 1965, 1975, 1985, 1995, 2005, and 2011. "X" denotes the core urban area. Data from Zhang et al. (2008) and Beijing Water Resource Bulletin (2011).

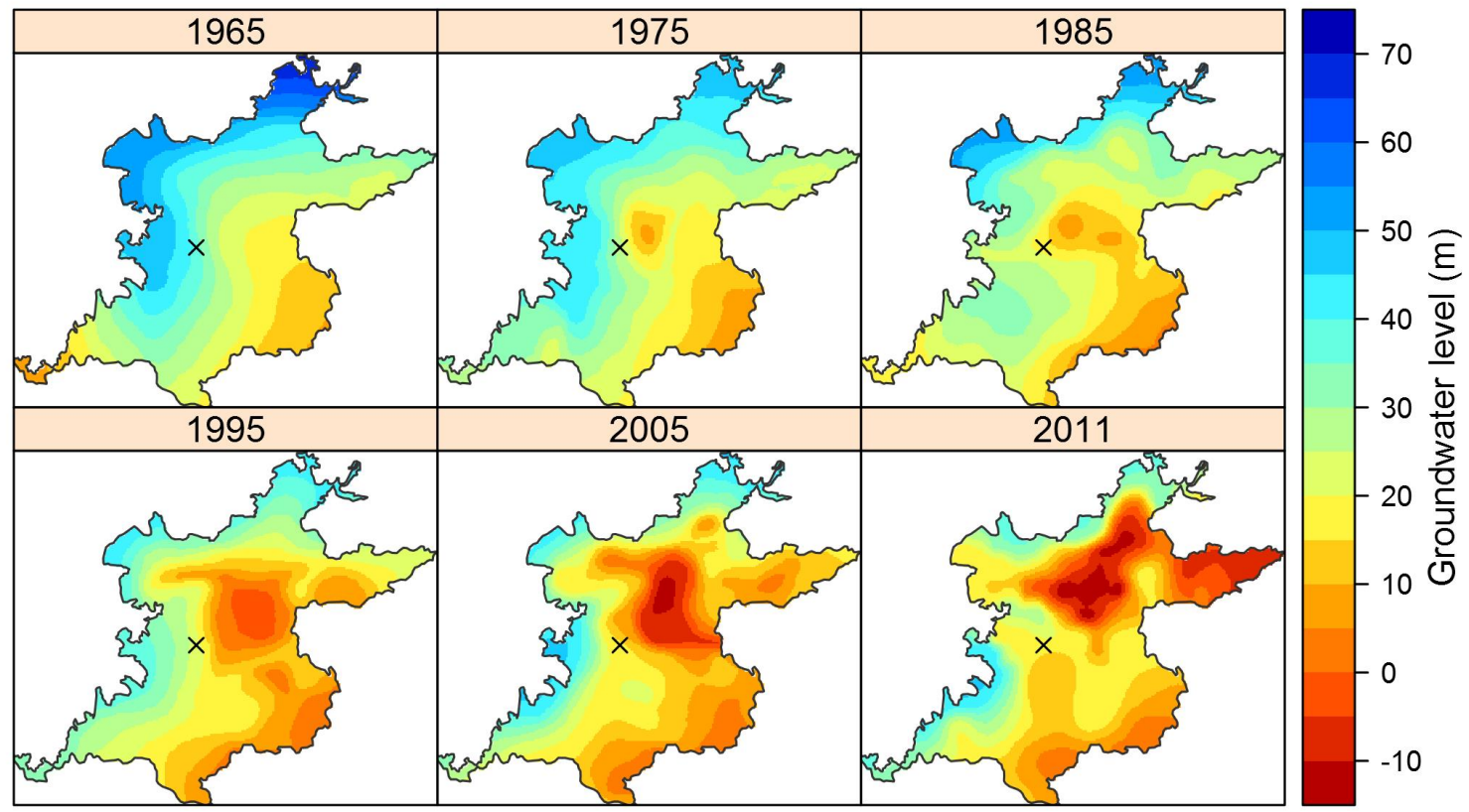

treatment, and water recycling technologies. For instance, to reduce industrial water use, the Beijing government gradually shut down or relocated water-intensive industries (e.g., iron and steel factories). In addition, between 1975 and 2011, the total area of farmland that was using water-saving irrigation techniques increased by 107 times (from 2.6 to 285.8 thousand ha) (Beijing Water Authority 2009-2011). From 2003 to 2014, a total of 6.6 billion $\mathrm{m}^{3}$ of wastewater was recycled and used (Fig. 5b). By the end of 2010, there were 1355 stormwater collection systems in Beijing that collected 50 million $\mathrm{m}^{3}$ of stormwater (Xinhuanet 2014). By the end of 2014, the number of stormwater collection systems had increased to 2150 , of which 1050 are in urban areas. In total, in 2014, Beijing collected 183 million $\mathrm{m}^{3}$ of stormwater: 104 million $\mathrm{m}^{3}$ in urban areas and 79 million $\mathrm{m}^{3}$ in rural districts (Chinanews 2015).

\section{Telecouplings}

Total natural water inflow to Beijing declined by approximately $91 \%$ (from 4.7 to 0.4 billion $\mathrm{m}^{3}$ ) from 1956 to 2014 (Fig. 3). The Guanting Reservoir (Fig. 2), approximately $100 \mathrm{~km}$ from the core urban area of Beijing and a water-sending system for Beijing, experienced a drastic decline in inflow since the 1950s (Fig. 3) due to climate variability, changes in upstream land cover and land use (Ma et al. 2010), and increases in water use in the upstream regions (Jiao 2008). Specifically, the inflow for the Guanting Reservoir declined from 2.0 billion $\mathrm{m}^{3} \cdot \mathrm{yr}^{-1}$ in the $1950 \mathrm{~s}$ to 0.1 billion $\mathrm{m}^{3} \cdot \mathrm{yr}^{-1}$ in the 2000s (Fig. 3). Upstream of the Guanting Reservoir, 267 reservoirs were built, $3636 \mathrm{~km}^{2}$ of previously uncropped land were developed for irrigated agriculture, and a large number of water-intensive industries (e.g., metallurgical, chemical, and electric power industries) were established since the 1950s (Jiao 2008). Industrial development upstream of the
Guanting Reservoir caused severe water pollution, which prevented its use for drinking water between 1997 and 2007. Since 1997, the Miyun Reservoir has been the main drinking water source for Beijing. This means that a change in the telecoupling process between the Guanting Reservoir and Beijing affects the local coupling process in terms of the change in water supply from the Miyun Reservoir.

In return, the local coupling processes may also influence the telecoupling process. There is now concern that the Miyun Reservoir might follow the trajectory of the Guanting Reservoir. Inflows to the Miyun Reservoir drastically declined from 3.0 billion $\mathrm{m}^{3} \cdot \mathrm{yr}^{-1}$ in the $1960 \mathrm{~s}$ to 0.3 billion $\mathrm{m}^{3} \cdot \mathrm{yr}^{-1}$ in the $2000 \mathrm{~s}$ (Fig. 3) due to reduced precipitation and increased upstream agricultural water use. In response to this deteriorating situation, the Paddy Land-to-Dry Land (PLDL) program was launched in 2006, which subsidized farmers in upper reaches to convert paddy land (rice) to dry land crops. This program was jointly implemented by the governments of Beijing (receiving system) and Hebei Province (sending system) to save water for Beijing (Zheng et al. 2013).

In addition, to address the large reduction in natural inflows, Beijing has been artificially diverting real water and importing virtual water from other sending systems. From 2005 to 2014, a total of 4.5 billion $\mathrm{m}^{3}$ of water was transferred from other regions to Beijing, including 1.57 billion $\mathrm{m}^{3}$ of water from the ongoing South-to-North Water Transfer Project (SNWTP) (Fig. 5b). The SNWTP is the world's longest and largest water transfer project with a planned total of 45 billion $\mathrm{m}^{3}$ of annual water transfer. The goal of this project is to divert water from the Yangtze River basin in South China to alleviate water shortages in North China, 
including Beijing (Yang and Zehnder 2005). The use of virtual water is much higher than that of real water, and is estimated to continue increasing with the growing consumption of meat and dairy (Huang et al. 2010). Although little research on virtual water for Beijing has been done (Zhang et al. 2011), one estimate suggests that between 1990 and 2005, the net import of virtual water into Beijing increased from 3.1 to 12.5 billion $\mathrm{m}^{3}$, of which approximately $90 \%$ was due to the import of agricultural products (Huang et al. 2010). Another recent estimate suggests that the net virtual water import into Beijing will be reduced to 10.7 billion $\mathrm{m}^{3}$ in 2030 (Zhao et al. 2015) under an optimistic scenario according to the new stringent water plan announced in 2011 (Liu and Yang 2012). In 2005, the estimated net import of virtual water was four times the amount of total real water use (Huang et al. 2010). In particular, the per capita virtual water use in 2005 for food was $1023 \mathrm{~m}^{3}(42.3 \%$ of which was through meat consumption), which was five times the per capita real water use (Wu et al. 2011).

The drastic reduction in natural inflows to Beijing also means a large decline in natural outflows from Beijing to downstream regions (spillover systems). The average total annual natural outflow from Beijing decreased by 55\% between the 1960s and 2000s (Fig. 3). For the Miyun and Guanting Reservoirs, the decadal average annual natural outflows declined by $45 \%$ and $64 \%$ between the 1990 s and 2000 s, respectively (Fig. 4). In contrast, the total annual wastewater discharge increased from approximately 1 billion $\mathrm{m}^{3}$ in 1988 to 1.5 billion $\mathrm{m}^{3}$ in 2012 . The discharge of industrial wastewater peaked in the late 1990s and has continuously declined since then. However, domestic wastewater discharge escalated from 0.5 billion $\mathrm{m}^{3}$ in 1988 to 1.4 billion $\mathrm{m}^{3}$ in 2012 (Beijing Water Authority 1986-2012).

Many agents (i.e., stakeholders) are involved in telecoupling processes, such as water users in Beijing who demand more clean water, officials in receiving and sending systems who negotiate water transfer agreements, and traders who facilitate the trade of virtual water. There are also feedbacks among sending, receiving, and spillover systems (Liu et al. 2016). For example, to receive more clean water from Hebei Province (sending system), Beijing provides payments to farmers in the province to reduce pollution and lower water use by planting corn instead of rice (Zheng et al. 2013). On the other hand, in response to the complaints from residents in the lower reaches (spillover systems), Beijing issued new policies in 2014 to compensate spillover systems for the polluted water it releases (Office of the People's Government of Beijing City 2014).

\section{EFFECTS OF WATER DYNAMICS}

While many factors affect water dynamics in Beijing through local couplings and telecouplings, the alteration of water dynamics in Beijing also leads to direct and indirect environmental and socioeconomic consequences, some of which may in turn affect water dynamics within and beyond Beijing via feedbacks. Some of those effects may be observable in a short period, while others may take decades to emerge. Here, we highlight the major effects.

\section{Environmental effects}

Human interrelations with water systems in Beijing have led to environmental consequences in the city as well as in water-sending and spillover systems. These include intermittent flows of rivers and lakes, degradation of riparian and aquatic ecosystems, loss of biodiversity, land subsidence, and deteriorating groundwater quality (Jiao 2008, Meng et al. 2012). While some effects may be reversible through restoration efforts (e.g., riparian wetland restoration), others are mostly irreversible (e.g., subsidence) or costly to treat or restore (e.g., treatment of eutrophication and groundwater contamination).

In Beijing, a series of environmental consequences has already been observed. Most rivers and tributaries near or within Beijing now have little or no water flow. A similar situation occurs with Beijing's lakes, many of which are essential components of famous waterscapes and cultural heritage sites, such as the Beihai, Kunming Lake, Yuanmingyuan (Old Summer Palace), and Zhongnanhai. In recent decades, almost all of these lakes were supplied with diverted water from the Guanting and Miyun Reservoirs or from pumped groundwater (Probe International Beijing Group 2008)

Exploitation of groundwater has led to significant ground subsidence. From 1955 to 2010, the area of Beijing that had subsidence greater than 50 and $100 \mathrm{~mm}$ was 4181 and $2815 \mathrm{~km}^{2}$, respectively (Du 2013). The subsidence continues, with an expansion rate of $30-60 \mathrm{~mm} \cdot \mathrm{yr}^{-1}$ (Du 2013). Subsidence often permanently alters the arrangement of sediment grains, making recovery impossible. Furthermore, ecosystems within or surrounding subsidence areas often suffer from modification of surface runoff and changes in land cover and land use (Zhang et al. 2008).

The effects of water issues in Beijing also spread to surrounding areas and distant regions in China (e.g., the water-sending regions of the SNWTP), and the rest of the world (e.g., pollutants are discharged into the ocean and spread through biogeochemical cycles). For example, the SNWTP involved extensive dam construction and river impoundment, which permanently destroyed vegetation cover and altered natural runoff in watersending systems (Yan et al. 2012). Dongping Lake near the Eastern Route of the SNWTP was estimated to have a 2- to 3-m water level increase, a $320-400 \mathrm{ton} / \mathrm{km}^{2}$ decrease in aquatic plant biomass, and associated consequences for other aquatic ecosystem components such as herbivore communities (Zhou et al. 1994, Wan et al. 2003). In addition, pumping groundwater and diverting water over distances consumes a large amount of energy. For example, the Eastern Route of the SNWTP depends on a total of 51 pumping stations, including 278 pumping machines that consume $529 \mathrm{MW}$ of energy per hour (China Institute of Water Resources and Hydropower Research 2013) to elevate water from the downstream Yangtze River to the North China Plain.

\section{Socioeconomic effects}

The socioeconomic effects of water dynamics in Beijing include damages from subsidence, impaired fisheries and decreased crop yields, costs to transform industrial structures and restore riparian and aquatic ecosystems, and health effects from water pollution. The economic costs of overpumping (i.e., exceeding the naturally renewable amount) are high. A conservative estimate of the cost of overpumping for Beijing was US\$1.5 per cubic meter ( $\mathrm{Li}$ and Shi 2003), which means that the cumulative cost was more than US\$16.7 billion between the 1960s and 2011. Yet this estimate does not fully account for many indirect costs such as subsidence, 
which is one of the most dangerous and costly consequences of overpumping (World Bank 2002). Subsidence damages infrastructure, including roads, bridges, pipelines, stormwater drainage systems, dams, and railways (Zhang et al. 2008). With regard to tap water pipelines in Beijing, for example, subsidence accounted for $34 \%$ of all the incidents of tap water pipeline damage between 2000 and 2006 (Zhang et al. 2008). A different example of economic cost from overpumping is the Old Summer Palace; its lake requires 10 million $\mathrm{m}^{3} \cdot \mathrm{yr}^{-1}$ of water from the Guanting Reservoir to maintain 1.5-2 $\mathrm{m}$ of water depth because the water table has declined far below the land surface in the region, thus water in the lake rapidly infiltrates downward to replenish groundwater. To address this problem, in 2004, the Palace authority proposed a US $\$ 3.6$ million budget to lay a plastic membrane at the bottom of the lake, which was rejected by ecologists and the municipal government and replaced with the use of recycled water and rainwater harvesting (Probe International Beijing Group 2008).

Water dynamics in Beijing also have led to mixed socioeconomic effects beyond Beijing. For the SNWTP, the Chinese government estimated that the total annual gross economic benefits would be as high as US\$8.5 billion (US\$1 = 6.47 yuan as of June 2016), including benefits from increased water supply, flood control, improved shipping, and other ecosystem services (Construction Committee Office of the South-North Water Transfer Project 2013). Considering the economic costs of environmental effects in water-sending regions, the net economic benefit will be only US\$0.7 billion annually (Lin et al. 2012). Besides the economic effects, there are also social effects. While the water transfer project resettles thousands of people, it also creates thousands of jobs. The Middle Route of SNWTP, for example, is estimated to displace 345,000 people, while the first phase of the Eastern and Middle Routes provided 180,000 temporary jobs every year during the construction period (Construction Committee Office of the South-North Water Transfer Project 2013).

\section{Feedback effects}

The water issues forced Beijing and other regional governments of water-sending regions to take actions both separately and jointly, including transforming the economic structure, restoring riparian areas, promoting water-efficient technologies, using recycled water, collecting stormwater, transferring water over long distances, and implementing payments for watershed services programs. These actions in turn affect water dynamics and people's livelihoods, both in Beijing and in water-sending and spillover systems, thereby forming feedback effects. For instance, increasing water shortages and pollution forced the Beijing government to enhance water use efficiency and improve the capacity of treatment facilities, thus reducing water use and partly alleviating water pollution (Fig. 7). Water use per 10,000 yuan of gross domestic product decreased by $83 \%$ from 2001 to 2014 , while the wastewater treatment rate increased from $7.6 \%$ in 1978 to $22.5 \%$ in 1998 and $86.1 \%$ in 2014 (Beijing Bureau of Statistics 1980-2015).

One feedback of concern is that the SNWTP could further stimulate population immigration, urbanization, and economic development in Beijing, and thus may increase water use, which would aggravate the water crisis instead of alleviating it. A recent study supports this concern and claims that neither real water transfer nor virtual water trade will play a major role in reducing water stress in water-receiving systems; rather, they will aggravate water stress in both water-sending and water-receiving systems in China (Zhao et al. 2015).

Fig. 7. Dynamics of surface water quality from 1997 to 2014. Grade classification is based on the Chinese Environmental Quality Standards for Surface Water (GB3838-2002). Grade I is the best quality. Grades I-III, IV, V, and $>$ V are classified as suitable for domestic and environmental uses, industrial use, agricultural use, and unusable, respectively. Data from Beijing Water Resource Bulletin (1997-2014).

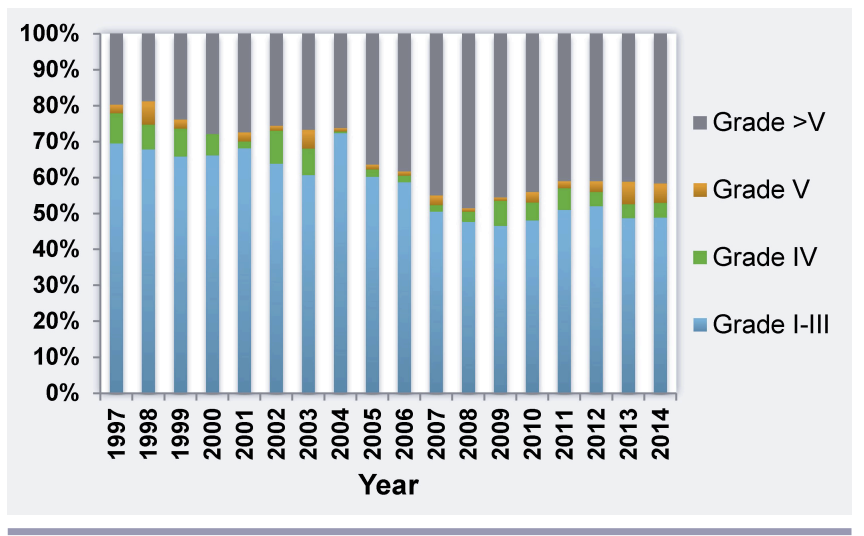

While many feedbacks aggravate the water crisis and further impair livelihoods, there are some promising signs stemming from policy interventions. The PLDL program is a case-in-point (Zheng et al. 2013). The assessment results show that the PLDL program on average increased surface runoff by $5 \%$ annually (or 18.2 million $\mathrm{m}^{3}$ ) and reduced the discharge of 10.4 tons of total nitrogen and 4.3 tons of phosphorus to the Miyun Reservoir (Zheng et al. 2013). The PLDL program not only reduced negative environmental effects but also improved participants' livelihoods. Compared to nonparticipants, average agricultural income of the participating households decreased by approximately US $\$ 330$ per year, whereas their income from migrant labor activities increased by US\$500 per year (Zheng et al. 2013). This is because participating households spent less labor cultivating corn than rice. Interestingly, the PLDL program also changed participants' consumption behaviors. For instance, participant households spent more on education, consumed more coal and liquefied natural gas than fuelwood, and invested more in household assets such as televisions, washing machines, refrigerators, and vehicles (Zheng et al. 2013). The SNWTP provides another example of improved livelihoods. From the perspective of equity and justice, the State Council is planning new payments for ecosystem services programs to offset the forgone socioeconomic benefits in the water-sending areas (Zheng and Han 2012).

\section{DISCUSSION AND CONCLUSIONS}

The application of the telecoupling framework illustrates that water dynamics in Beijing are affected by many local coupling and telecoupling processes, and that water dynamics affect many human and natural components within and beyond Beijing. Viewing urban areas such as Beijing as a part of a telecoupled human and natural system helps to more systematically study 
water dynamics in a megacity as a water-receiving system while at the same time considering its relationships with sending and spillover systems.

Numerous recommendations have been made regarding water management for Beijing (e.g., increasing efficiency of water use, expanding water supply through water transfer, reuse, desalinization, and stormwater collection), but telecouplings and their interactions with local couplings have not been systematically studied, let alone effectively incorporated into policy. We provide several policy recommendations to integrate local couplings and telecouplings as well as their interactions. Over the long run, effective water management measures require monitoring and managing factors that directly and indirectly drive water use behaviors (Liu and Yang 2012).

In terms of local couplings, an important way to achieve water sustainability is to control total water demand and reduce activities (e.g., agricultural production) that require large amounts of water. Nevertheless, local actions may also affect sending and spillover systems. Water sustainability at national and global levels requires overall reduction in water use, which cannot be achieved without a holistic approach, as shown in the telecoupling framework. Among China's cities, Beijing has been a pioneer in reducing water use through multiple measures such as setting maximum water use quotas for different sectors and entities, reforming the water price system (e.g., raising prices and implementing block tariffs) to discourage high usage, and offering incentives (e.g., cash rewards, tax concessions) to water-saving technologies and equipment (Ma et al. 2011, Hao 2012, Meng et al. 2012). Although these measures are laudable, they may not be sufficient to substantially change the behavior of many water users. For example, water prices have been found to be an effective tool mostly for low-income users, yet prices may have less effect on the behavior of many top water users who tend to be wealthy people or entities (Olmstead et al. 2007, Jorgensen et al. 2009, Olmstead and Stavins 2009). In such cases and more generally, complementary measures (e.g., public education, public monitoring and disclosure of long-term top water users, and noneconomic penalties such as mandatory community services of top water users) should also be considered (Nieswiadomy 1992 , Gleick 2003). There is no one-size-fits-all approach, and the combination of "hard paths" (e.g., engineering projects) and "soft paths" (e.g., public education and engagement, incentive programs) is often indispensable (Gleick 2003, Liu and Yang 2012).

Management of water demand must also recognize the social and equity aspects of water pricing and policy. The United Nations has declared access to water for personal and domestic uses a basic human right (UN-OHCHR 2010). Although this right does not provide for free or unlimited water, it does state that meeting basic needs must be affordable to the poor (UN-OHCHR 2010). Though economic efficiency and conservation may seem to be in conflict with social and equity concerns, well-conceived pricing systems and policies can enhance both goals (OECD 2003, Peña 2011). For example, basic water needs can be guaranteed for all at low cost (e.g., below recovery costs), but water use beyond basic needs can be priced and allocated to consider economic and environmental objectives (OECD 2003, Barraqué and Montginoul 2015). One possible approach is adapted block rate structures, sometimes referred to as block rates based on water budgets, which allocates a block of water at a low price to all households based on the characteristics of the households, such as number of people, but then charges increasing rates for larger amounts of water use. Such systems promote water conservation through price signals while also maintaining fiscal balance and promoting equity (Baerenklau et al. 2014, Chan 2015). The telecoupling framework offers a valuable tool to further understand social and equity issues of water use by considering effects on water outside a specific area. Equity and justice dimensions of urbanization processes can be addressed by the telecoupling framework because they can be causes and/or effects of telecoupling. For example, rural-to-urban migration is an important telecoupling process that contributes to urbanization. Some migrants from rural areas relocate to the cities because they are not treated fairly by local rural governments (a cause for the migration). The migrants often experience inequity and injustice in the cities, as they and their children may not be treated equally in job, education, and other opportunities (an effect of the migration).

Disconnecting or reducing some local couplings and telecouplings is another way to reduce water demand in Beijing. Beijing has already moved some heavy industries to other provinces (Hao 2012), thus disconnecting some local couplings. However, it is necessary to close or move more additional heavy water users and polluters out of Beijing to areas with more abundant water supplies. Another way to manage telecouplings is to control population immigration. As the capital of a country with centralized power, Beijing has unique political power to shape telecoupling processes such as the South-to-North Water Transfer Project. With regard to other telecoupling processes such as migration, however, even Beijing's power is limited. Although the city government has requested immigration controls (Beijing Municipal People's Government 2010), it is a politically and socially sensitive issue because Beijing offers more opportunities for education and jobs than other areas. Reducing opportunity inequality between Beijing and other areas would help make such controls feasible. Instead of coming to work and consuming real and virtual water in Beijing every day, some workers could work from homes distant from the city.

It is in Beijing's long-term interest to nurture water-sending systems and reduce negative effects on spillover systems because the city continuously depends on sending systems and has feedback effects from both sending and spillover systems. One option is to expand payments for ecosystem services like the PLDL program (or compensate the negative environmental effects resulting from virtual water trade and real water transfer to Beijing). The payments for ecosystem services programs may encourage activities in sending systems to use less water, through technological aid or compensation for crop substitution and the operation of businesses using less water (Liu and Yang 2013, Zheng et al. 2013). However, it is important to go beyond bilateral agreements between water-sending and water-receiving systems that do not consider spillover systems, such as other areas that affect or are affected by the SNWTP (Liu and Yang 2013). For example, if other areas receive contaminated wastewater from Beijing, this could contaminate crops and supply unsafe food to Beijing. 
Our analysis also reveals multiple research gaps, including little quantification of the relative importance of local coupling and telecoupling processes and their interactions in water dynamics. There are shortages of data and incomplete knowledge on spillover systems and feedbacks. For example, the number and type of spillover systems related to water dynamics of Beijing are not well documented, let alone fully understood. There is little understanding of environmental and socioeconomic effects on the many spillover systems. Quantitative information about the many complexities of the effects (e.g., time lags, legacy effects, nonlinearities, and thresholds) is also insufficient (Liu et al. 2007). Filling these and other gaps requires a holistic approach as conceptualized in the telecoupling framework described here because the framework explicitly considers various components and their interactions. While it is impossible to demonstrate all the utilities of the telecoupling framework in one paper, identifying knowledge gaps is one of our goals. It provides an important conceptual advance and a good foundation for future research efforts to collect relevant data for filling these gaps.

We have shown that the telecoupling framework can help systematically understand and manage major issues related to water dynamics in the Beijing region. Instead of considering local couplings and telecouplings separately, as is done in other frameworks, the telecoupling framework considers local and telecoupling processes as well as their interactions simultaneously. Such integrated analyses can provide a basis for more effective policies that would address water sustainability challenges holistically. For example, more policy interventions involving water-sending and spillover systems are needed. Because Beijing shares many attributes with the 21 other megacities, such as Los Angeles and Sao Paulo, which depend on distant water transfers, the telecoupling framework and some findings and recommendations for Beijing are likely applicable to other megacities.

Responses to this article can be read online at: http://www.ecologyandsociety.org/issues/responses. $\mathrm{php} / 8685$

\section{Acknowledgments:}

We thank the fund from Michigan State University's CWS-ESPP Water Innovation Research Grant, U.S. National Science Foundation and Michigan AqBioResearch, and Zhejiang University's 100-Talent Plan. We thank William McConnell and Susanne Nichols for comments and edits on an earlier draft. We also appreciate the very constructive comments and suggestions from Dr. Lance Gunderson, the anonymous subject editor, and reviewers.

\section{LITERATURE CITED}

Abraham, W.-R. 2010. Megacities as sources for pathogenic bacteria in rivers and their fate downstream. International Journal of Microbiology 2011:1-13. http://dx.doi.org/10.1155/2011/798292

Baerenklau, K. A., K. A. Schwabe, and A. Dinar. 2014. The residential water demand effect of increasing block rate water budgets. Land Economics 90:683-699. http://dx.doi.org/10.3368/ le. 90.4 .683

Bai, Y., Z. Y. Ouyang, H. Zheng, X. M. Li, C. W. Zhuang, and B. Jiang. 2012. Modeling soil conservation, water conservation and their tradeoffs: a case study in Beijing. Journal of Environmental Sciences-China 24:419-426. http://dx.doi.org/10.1016/s1001-0742 (11) $60790-0$

Barraqué, B., and M. Montginoul. 2015. How to integrate social objectives into water pricing. Pages $359-371$ in A. Dinar, V. Pochat, and J. Albiac-Munillo, editors. Water pricing experiences and innovations. Springer, Switzerland. http://dx.doi. org/10.1007/978-3-319-16465-6 18

Beijing Bureau of Statistics. 1980-2015. Beijing Statistic Yearbook. Beijing, China.

Beijing Municipal People's Government. 2010. The $12^{\text {th }}$ five-year plan for economic and social development of Beijing. Beijing, China.

Beijing Water Authority. 1986-2012. Beijing Water Resources Bulletin. Beijing, China.

Beijing Water Authority. 2009-2011. Beijing water statistic yearbook 2009-2011. Beijing, China.

Beijing Water Authority \& Beijing Bureau of Statistics. 2013. Bulletin of first Beijing census for water. China Water Power Press, Beijing, China.

Bidhendi, G. N., T. Nasrabadi, H. R. Vaghefi, H. Hoveidi, and H. R. Jafari. 2008. Role of water-saving devices in reducing urban water consumption in the mega-city of Tehran, case study: a residential complex. Journal of Environmental Health 70:44 47.

Binder, C. R., J. Hinkel, P. W. G. Bots, and C. Pahl-Wostl. 2013. Comparison of frameworks for analyzing social-ecological systems. Ecology and Society 18(4):26. http://dx.doi.org/10.5751/ es-05551-180426

Bithas, K. 2011. Sustainability and externalities: Is the internalization of externalities a sufficient condition for sustainability? Ecological Economics 70:1703-1706. http://dx.doi. org/10.1016/j.ecolecon.2011.05.014

Bloom, D. E. 2011.7 billion and counting. Science 333:562-569. http://dx.doi.org/10.1126/science.1209290

Brock, W., and A. Xepapadeas. 2010. Pattern formation, spatial externalities and regulation in coupled economic-ecological systems. Journal of Environmental Economics and Management 59:149-164. http://dx.doi.org/10.1016/j.jeem.2009.07.003

Chan, N. W. W. 2015. Integrating social aspects into urban water pricing. Pages 311-336 in Q. Grafton, K. A. Daniell, C. Nauges, J.-D. Rinaudo, and N. W. W. Chan, editors. Understanding and managing urban water in transition. Springer, Netherlands.

China Institute of Water Resources and Hydropower Research. 2013. 13 water pumping ladder stations elevating water 65 meters and allowing water to flow uphill. [title translated from Chinese] [online] URL: http://www.iwhr.com/zgskyww/ztbd/nsbd/dsbf/ webinfo/2013/03/1360423717677225.htm

Chinanews. 2015. Beijing investing 400 million yuan RMB as special funds to build a full range of water-saving "sponge City". 
[title translated from Chinese] [online] URL: http://finance. chinanews.com/ny/2015/05-14/7276644.shtml

Construction Committee Office of the South-North Water Transfer Project. 2013. Official site of the South-North Water Transfer Project. [title translated from Chinese] [online] URL: http://www.nsbd.gov.cn

Deines, J. M., X. Liu, and J. G. Liu. 2016. Telecoupling in urban water systems: an examination of Beijing's imported water supply. Water International 41:251-270. http://dx.doi.org/10.1080/0250$\underline{8060.2015 .1113485}$

Du, Z. 2013. Analysis of the formation mechanism of uneven ground subsidence in the typical region of Beijing. Capital Normal University, Beijing, China.

Eakin, H., R. DeFries, S. Kerr, E. F. Lambin, J. Liu, P. J. Marcotullio, P. Messerli, A. Reenberg, X. Rueda, S. R. Swaffield, B. Wicke, and K. Zimmerer. 2014. Significance of telecoupling for exploration of land-use change. Pages 141-161 in K. Seto and A. Reenberg, editors. Rethinking global land use in an urban era. MIT Press, Cambridge, Massachusetts, USA. http://dx.doi. org/10.7551/mitpress/9780262026901.003.0008

Falkenmark, M., and C. Widstrand. 1992. Population and water resources: a delicate balance. Population Bulletin, Population Reference Bureau, Washington, D.C., USA.

Gasparri, N. I., T. Kuemmerle, P. Meyfroidt, Y. le Polain de Waroux, and H. Kreft. 2015. The emerging soybean production frontier in southern Africa: conservation challenges and the role of south-south telecouplings. Conservation Letters 9:21-31. http://dx.doi.org/10.1111/conl.12173

Gleick, P. H. 1995. Human population and water: to the limits in the 21st century. American Association for the Advancement of Science Symposium 1995, Washington, D.C., USA.

Gleick, P. H. 2003. Global freshwater resources: soft-path solutions for the 21st century. Science 302:1524-1528. http://dx. doi.org/10.1126/science.1089967

Hao, X. 2012. A megacity held hostage: Beijing's conflict between water and economy. Water 21 6:39-42.

Huang, J., Z. Song, and F. Chen. 2010. Characteristics of water footprint and agricultural water structure in Beijing. Acta Ecologia Sinica 30:6546-6554.

Jenerette, G. D., and L. Larsen. 2006. A global perspective on changing sustainable urban water supplies. Global and Planetary Change 50:202-211. http://dx.doi.org/10.1016/j.gloplacha.2006.01.004

Jiao, Z. 2008. Theory and practice of circulating water. China Waterpower Press, Beijing, China.

Jorgensen, B., M. Graymore, and K. O'Toole. 2009. Household water use behavior: an integrated model. Journal of Environmental Management 91:227-236. http://dx.doi.org/10.1016/j.jenvman.2009.08.009

Li, X., and H. Shi. 2003. Calculation method for economic loss caused by overmining of groundwater and its application to typical regions. [title translated from Chinese] Advances in Science and Technology of Water Resources 23:13-20.
Li, X., W. Zhou, and Z. Ouyang. 2013. Forty years of urban expansion in Beijing: What is the relative importance of physical, socioeconomic, and neighborhood factors? Applied Geography 38:1-10. http://dx.doi.org/10.1016/j.apgeog.2012.11.004

Lin, C., S. Suh, and S. Pfister. 2012. Does south-to-north water transfer reduce the environmental impact of water consumption in China? Journal of Industrial Ecology 16:647-654. http://dx.doi. org/10.1111/j.1530-9290.2012.00500.x

Liu, J. 2014. Forest sustainability in China and implications for a telecoupled world. Asia \& the Pacific Policy Studies 1:230-250. http://dx.doi.org/10.1002/app5.17

Liu, J., G. C. Daily, P. R. Ehrlich, and G. W. Luck. 2003 Effects of household dynamics on resource consumption and biodiversity. Nature 421:530-533. http://dx.doi.org/10.1038/ $\underline{\text { nature } 01359}$

Liu, J., T. Dietz, S. R. Carpenter, M. Alberti, C. Folke, E. Moran, A. N. Pell, P. Deadman, T. Kratz, J. Lubchenco, E. Ostrom, Z. Ouyang, W. Provencher, C. L. Redman, S. H. Schneider, and W. W. Taylor. 2007. Complexity of coupled human and natural systems. Science 317:1513-1516. http://dx.doi.org/10.1126/ science. 1144004

Liu, J., V. Hull, M. Batistella, R. DeFries, T. Dietz, F. Fu, T. W. Hertel, R. C. Izaurralde, E. F. Lambin, S. Li, L. A. Martinelli, W. McConnell, E. F. Moran, R. Naylor, Z. Ouyang, K. R. Polenske, A. Reenberg, G. d. M. Rocha, C. S. Simmons, P. H. Verburg, P. M. Vitousek, F. Zhang, and C. Zhu. 2013. Framing sustainability in a telecoupled world. Ecology and Society 18(2):26. http://dx. doi.org/10.5751/es-05873-180226

Liu, J., V. Hull, J. Luo, W. Yang, W. Liu, A. Viña, C. Vogt, Z. Xu, H. Yang, J. Zhang, L. An, X. Chen, S. Li, W. McConnell, Z. Ouyang, W. Xu, and H. Zhang. 2015a. Multiple telecouplings and their complex interrelationships. Ecology and Society 20(3):44. http://dx.doi.org/10.5751/es-07868-200344

Liu, J., V. Hull, E. Moran, H. Nagendra, S. Swaffield, and B. L. Turner II. 2014. Applications of the telecoupling framework to land-change science. Pages 119-139 in K. Seto and A. Reenberg, editors. Rethinking global land use in an urban era. MIT Press, Cambridge, Massachusetts, USA. http://dx.doi.org/10.7551/ mitpress/9780262026901.003.0007

Liu, J., H. Mooney, V. Hull, S. J. Davis, J. Gaskell, T. Hertel, J. Lubchenco, K. C. Seto, P. Gleick, C. Kremen, and S. Li. $2015 b$. Systems integration for global sustainability. Science 347:1258832. http://dx.doi.org/10.1126/science.1258832

Liu, J., and W. Yang. 2012. Water sustainability for China and beyond. Science 337:649-650. http://dx.doi.org/10.1126/science.1219471

Liu, J., and W. Yang. 2013. Integrated assessments of payments for ecosystem services programs. Proceedings of the National Academy of Sciences of the United States of America 110:1629716298. http://dx.doi.org/10.1073/pnas. 1316036110

Liu, J., W. Yang, and S. Li. 2016. Framing ecosystem services in the telecoupled Anthropocene. Frontiers in Ecology and the Environment 14:27-36. http://dx.doi.org/10.1002/16-0188.1 
Lorenzen, G., C. Sprenger, T. Taute, A. Pekdeger, A. Mittal, and G. Massmann. 2010. Assessment of the potential for bank filtration in a water-stressed megacity (Delhi, India). Environmental Earth Sciences 61:1419-1434. http://dx.doi. org/10.1007/s12665-010-0458-X

Ma, D., H. Hu, and T. Chen. 2011. Study on the government management function and mode of water rights. [title translated from Chinese] China Water Power Press, Beijing, China.

Ma, H., D. Yang, S. K. Tan, B. Gao, and Q. Hu. 2010. Impact of climate variability and human activity on streamflow decrease in the Miyun Reservoir catchment. Journal of Hydrology 389:317324. http://dx.doi.org/10.1016/j.jhydrol.2010.06.010

Mansell, M., and S. Wang. 2010. Water balance modelling in Glasgow and Beijing. Proceedings of the Institution of Civil Engineers-Water Management 163:219-226. http://dx.doi. org/10.1680/wama.2010.163.5.219

McDonald, R. I., K. Weber, J. Padowski, M. Flörke, C. Schneider, P. A. Green, T. Gleeson, S. Eckman, B. Lehner, D. Balk, T. Boucher, G. Grill, and M. Montgomery. 2014. Water on an urban planet: urbanization and the reach of urban water infrastructure. Global Environmental Change 27:96-105. http://dx.doi. org/10.1016/j.gloenvcha.2014.04.022

Meng, Q., Z. Ouyang, and D. Ma. 2012. Water ecosystem service assessment and valuation in Beijing. [title translated from Chinese] China Science Press, Beijing, China.

Nieswiadomy, M. L. 1992. Estimating urban residential water demand: effects of price structure, conservation, and education. Water Resources Research 28:609-615. http://dx.doi. org/10.1029/91WR02852

Office of the People's Government of Beijing City. 2014. Regional compensation method for Beijing's water environment (trial version). Beijing. [title translated from Chinese] [online] URL: http://zhengwu.beijing.gov.cn/gzdt/gggs/t1376586.htm

Olmstead, S. M., W. M. Hanemann, and R. N. Stavins. 2007. Water demand under alternative price structures. Journal of Environmental Economics and Management 54:181-198. http:// dx.doi.org/10.1016/j.jeem.2007.03.002

Olmstead, S. M., and R. N. Stavins. 2009. Comparing price and nonprice approaches to urban water conservation. Water Resources Research 45:W04301. http://dx.doi.org/10.1029/2008wr007227

Organisation for Economic Co-Operation and Development (OECD). 2003. Social issues in the provision and pricing of water services. Paris, France.

Ostrom, E. 2009. A general framework for analyzing sustainability of social-ecological systems. Science 325:419-422. http://dx.doi.org/10.1126/science.1172133

Peña, H. 2011. Social equity and integrated water resources management. Global Water Partnership, Stockholm, Sweden.

Probe International Beijing Group. 2008. Beijing's water crisis: 1949-2008 Olympics.

Sohel, K., M. Chowdhury, and M. Ahmed. 2003. Surface water quality in and around Dhaka City. Aqua 52:141-153.
Tortajada, C., and E. Castelán. 2003. Water management for a megacity: Mexico City metropolitan area. Ambio 32:124-129. http://dx.doi.org/10.1579/0044-7447-32.2.124

UN-HABITAT. 2008. State of the world's cities 2010/2011. United Nations Human Settlements Programme, Sterling, VA.

United Nations. 1998. Trends in urbanization and the components of urban growth.In Proceedings of the Symposium on Internal Migration and Urbanization in Developing Countries, January 22-24, 1996. United Nations Population Fund, New York, USA.

United Nations. 2014. World urbanization prospects: the 2014 revision. New York, USA.

United Nations, Department of Economic and Social Affairs (UN-DESA). 2014. World urbanization prospects: the 2014 revision. Population Division.

United Nations Office of the High Commissioner for Human Rights (UN-OHCHR). 2010. The right to water. Fact Sheet No. 35. Geneva, Switzerland.

Varis, O., A. K. Biswas, C. Tortajada, and J. Lundqvist. 2006. Megacities and water management. International Journal of Water Resources Development 22:377-394. http://dx.doi. org/10.1080/07900620600684550

Wackernagel, M., and W. E. Rees. 1996. Our ecological footprint: reducing human impact on the Earth. New Society Publishers, Philadelphia, Pennsylvania, USA.

Wan, Y., Y. Huang, and H. Wang. 2003. EIA and protection measures for the adjusting and storing Lake Marsh of the East Route Project of south to north water transfer. Research of Environmental Sciences 16:5-11.

Wicke, B. 2014. Telecouplings and their implications for land use: palm oil as a case study. Pages 163-181 in K. Seto and A. Reenberg, editors. Rethinking global land use in an urban era. MIT Press, Cambridge, Massachusetts, USA.

Wolman, A. 1965. The metabolism of cities. Scientific American 213:179-190.

World Bank. 2002. China agenda for water sector strategy for North China: summary report. World Bank, Washington D.C., USA.

Wu, Y., X. Wang, and F. Lu. 2011. Ecological footprint and water footprint of food consumption in Beijing. Resources Science 33:1145-1152.

World Wildlife Fund (WWF). 2011. Big cities. Big water. Big challenges. Water in an urbanizing world. Berlin, Germany.

Xinhuanet. 2014. Multisectoral collaboration to promote rainwater harvesting. [title translated from Chinese] [online] URL: http:// news.xinhuanet.com/energy/2014-10/27/c 1112991199.htm

Yan, C., editor. 1999. Fifty years of water conservancy of Beijing. Water Power Press, Beijing, China.

Yan, D. H., H. Wang, H. H. Li, G. Wang, T. L. Qin, D. Y. Wang, and L. H. Wang. 2012. Quantitative analysis on the environmental impact of large-scale water transfer project on water resource area 
in a changing environment. Hydrology and Earth System Sciences 16:2685-2702. http://dx.doi.org/10.5194/hess-16-2685-2012

Yang, H., and A. J. B. Zehnder. 2005. The South-north Water Transfer Project in China: an analysis of water demand uncertainty and environmental objectives in decision making. Water International 30:339-349. http://dx.doi.org/10.1080/0250$\underline{8060508691874}$

Zhang, A., C. Ye, Y. Li, and Z. Xie, editors. 2008. Beijing's groundwater. [title translated from Chinese] $1^{\text {st }}$ edition. China Land Press, Beijing, China.

Zhang, Y., Z. Yang, and B. D. Fath. 2010. Ecological network analysis of an urban water metabolic system: model development, and a case study for Beijing. Science of the Total Environment 408:4702-4711. http://dx.doi.org/10.1016/j.scitotenv.2010.06.019

Zhang, Z., H. Yang, and M. Shi. 2011. Analyses of water footprint of Beijing in an interregional input-output framework. Ecological Economics 70:2494-2502. http://dx.doi.org/10.1016/j.

ecolecon.2011.08.011

Zhao, X., J. Liu, Q. Liu, M. R. Tillotson, D. Guan, and K. Hubacek. 2015. Physical and virtual water transfers for regional water stress alleviation in China. Proceedings of the National Academy of Science of the United States of America 112:10311035. http://dx.doi.org/10.1073/pnas. 1404130112

Zheng, J., and D. Han. 2012. River basin environments and ecological succession in Danjiangkou Reservoir. Pages 211-241 in B. Han and Z. Liu, editors. Tropical and sub-tropical reservoir limnology in China. Springer, Dordrecht, Netherlands. http://dx. doi.org/10.1007/978-94-007-2007-7 13

Zheng, H., B. E. Robinson, Y.-C. Liang, S. Polasky, D.-C. Ma, F.C. Wang, M. Ruckelshaus, Z.-Y. Ouyang, and G. C. Daily. 2013. Benefits, costs, and livelihood implications of a regional payment for ecosystem service program. Proceedings of the National Academy of Sciences of the United States of America 110:1668116686. http://dx.doi.org/10.1073/pnas. 1312324110

Zhou, W., X. Guo, W. Chen, W. Hu, K. Chen, S. Zhang, G. Sui, B. Ren, and M. Wu. 1994. Prediction of effects of first stage project of eastern route south-to-north water transfer from the Changjiang River on aquatic organism and ecological environment in Hongze Lake. [title translated from Chinese] Journal of Lake Sciences 6:131-135. http://dx.doi.org/10.18307/1994.0205

Zhou, R., P. Shui, and Y. Li. 2013. Technical manual for Beijing drought control. [title translated from Chinese] China Water Power Press, Beijing, China. 